\title{
Girls talk: authorship and authenticity in the reception of Lena Dunham's Girls
}

Article

Accepted Version

Woods, F. (2015) Girls talk: authorship and authenticity in the reception of Lena Dunham's Girls. Critical Studies in

Television, 10 (2). pp. 37-54. ISSN 1749-6020 doi:

https://doi.org/10.7227/CST.10.2.4 Available at

https://centaur.reading.ac.uk/40842/

It is advisable to refer to the publisher's version if you intend to cite from the work. See Guidance on citing.

Published version at: http://www.ingentaconnect.com/content/manup/cstv/2015/00000010/00000002/art00004

To link to this article DOI: http://dx.doi.org/10.7227/CST.10.2.4

Publisher: Manchester University Press

All outputs in CentAUR are protected by Intellectual Property Rights law, including copyright law. Copyright and IPR is retained by the creators or other copyright holders. Terms and conditions for use of this material are defined in the End User Agreement.

\section{www.reading.ac.uk/centaur}

\section{CentAUR}

Central Archive at the University of Reading

Reading's research outputs online 
Girls Talk: Authorship and Authenticity in the Reception of Lena Dunham's Girls

\author{
Special Issue on Gender and Comedy
}

\begin{abstract}
By examining the discourse around Lena Dunham's HBO comedy Girls, this article argues that the programme served as a space to think through female authorship, televisual representations and cultural tensions surrounding young womanhood. Central to this discourse was the narrative asserting Girls' and Dunham's 'authenticity', originality and universality, which sought to legitimate her gendered authorship and interest in the comedy of female intimacy within HBO's masculine prestige channel identity. Charting three cycles of discourse surrounding the programme's debut, this article explores the paratextual framing by promotional concerns, television critics and women's websites. It highlights how journalists and critics furthered HBO's paratextual framing of Dunham, which was later countered by the networked spaces of niche online media, which used the programme as a space to productively work through industrial and cultural tensions; particularly those surrounding female comic authorship, autobiography and intersectionality.
\end{abstract}

Gender; Race; Authorship; HBO; Television; New Media

Lena Dunham's HBO comedy Girls (2012-) arrived on US television screens accompanied by a wave of hype and critical praise for its singular 'voice' and the fearlessness of its representation of young womanhood. In a US television industry where women rarely reach thirty per cent of all writers and showrunners (Ryan 2012b), Girls offered a rare programme created, written, directed and starring a twenty-something woman, particularly on a channel dominated by white male 'auteurs'. This low-key comedy about a quartet of privileged white women's awkward, struggling twenties in Brooklyn, New York became the centre of a cultural storm, forcing to the surface conversations that had circulated in female-focused online spaces in recent years. Girls served as a catalyst across a range of online and print media for conversations around television and race, gender and comedy, authorship and industry, class and privilege, bodies and sexuality.

This article explores the industrial hype and dense swirl of cultural commentary surrounding Girls, where it was treated less like a low-key comedy of twenty-something struggle and more like a generational document. It highlights the impact of spreadable (Jenkins, Ford, and Green 2013) television commentary in the web 2.0 era, charting how cultural conversations can be influenced by a diversity of voices beyond traditional critical gatekeepers (Gray 2010b), particularly when engaging with concerns around gender, class and race. In privileging analysis of discourse over an analysis of the programme itself I draw out the role of paratexts - promotional trailers, profiles and interviews, television critics' reviews and essays on women's websites - in the wider cultural framing of Girls. This discourse offered polysemic and intersectional interventions, with the third cycle continuing long traditions of women's participatory talk about television and the construction of community (Brown 1994).

In this case 'Girls talk' was facilitated by the networked spread of culture websites and women's websites, with the active and reactive circulation of cultural commentary beyond traditional promotional and critical discourses. Through this Girls became a valuable 
cultural object in on-going discourses around women's bodies, contemporary feminism, normative femininity, the boundary-pushing feminist potential of female-authored comedy (Mizejewski 2014) and the limitations of US television's representations of women and people of colour. This conversation amongst a diverse range of voices serves as an example of how television is produced and made complex through discussion and active consumption.

Girls undoubtedly serves as a complex and productive site through which to examine topics such as contemporary Western femininity, (post)feminism and labour and televisual explorations of female friendship. The programme is a growing topic of academic study, explored at academic conferences (Petersen 2014; Jones 2014) and on academic blogs (Amanda Ann Klein 2014; Wheatley 2013). Undoubtedly more work will follow Taylor Nygaard's perceptive contextual industrial analysis (2013) - the highlight of a collection of articles on Girls in Feminist Media Studies - and Stephania Marghitu and Conrad Ng's interweaving of analysis of Dunham's employment of her body with the post-feminist discourse around the programme (2013). Cultural discussion of Girls developed throughout its first and second seasons (falling to a whisper by its third and fourth). I focus here primarily on the discourse leading up to and within the first few weeks of the premiere, drawing on Jonathan Gray to frame this as a series of paratextual cycles establishing 'meanings and frames for decoding before the audience member has even encountered the film or television program' $(2010 \mathrm{a}, 18)$. The sheer mass of commentary makes it untenable to cover in single article, so I focus on key concerns - particularly authorship, 'authenticity' and race - to map the gendered comedy of Girls in conversation.

I highlight how the promotional discourse sought to positioned Dunham as an auteur showrunner, serving to 'legitimate' (Newman and Levine 2011) the show's young, female, relationship-focused comedy through a focus on its 'authenticity', $\mathrm{i}$ and serving to integrate Girls into HBO's channel identity of prestige television. ${ }^{\text {ii }}$ This discourse was then largely taken up and reinforced by television critics in the second cycle, before it was problematized by online critiques in the third cycle. ${ }^{\text {iii }}$ This cultural conversation questioned the previous cycles' assertions of universality and authenticity, arguing that the programme offered a very particular, limited, worldview. Such commentary brought issues of privilege to the fore, highlighting the default to whiteness and erasure of people of colour within a comedy lauded for its progressive presentation of women's experience. Illustrating Gray's assertion that paratextual study 'promises to tell us how a text creates meaning in popular culture and society more generally' $(2010 \mathrm{a}, 26)$, this discourse brought mainstream press attention to questions that were always already being worked through in the network of women's websites and social media. I suggest that Dunham's comedy served as a space to think through the contradictions and challenges of contemporary femininity and women's place in television.

\section{Situating Girls}

Girls arrived late (April 2012) in a 2011-12 US television season where women and comedy - and particularly the 'girl' - were already part of the cultural conversation. A wave of female-fronted network sitcoms had debuted that season, following in the footsteps of that summer's blockbuster success, Bridesmaids (2011). Whilst these sitcoms had been piloted and added to the Autumn schedules before the film's release, its raucous comedy of female friendship from writing duo Annie Mumolo and Kristen Wiig had made women and comedy a cultural talking point. Seven sitcoms created by women appeared across all four networks, 
primarily chronicling the experiences of white, heterosexual, twenty-something women, including 2 Broke Girls (2011-), New Girl (2011-) and Don't Trust the B--- in Apartment 23 (2012-13). Press coverage foregrounded the shows' female authorship (Carter 2011; Press 2011) although nearly all these women were assigned male co-showrunners and women remained in the minority in their writing rooms. Thus conversations around comedy, authorship and representation were already circulating (Nussbaum 2011; Rosenberg 2012a; Sepinwall 2012a) serving to shape the reception of Girls.

These sitcoms can be viewed as a post-Sex and the City (1998-2004) generation of female-focused comedy, targeting an audience raised on cable reruns of the HBO programme carefully trimmed of its more risqué content. They were the televisual younger sisters of former Saturday Night Live (1975-) stars Tina Fey and Amy Poehler, whose comic creations Liz Lemon (30 Rock (2006-2013)) and Leslie Knope (Parks and Recreation (2009-2014)) negotiated the complexities of contemporary female identity and installed Fey and Poehler as feminist comedy icons. Jane Arthurs positions Sex and the City as HBO's answer to the 1990s rise of network postfeminist dramas, niche targeting affluent female audiences (2003, 42) through an intertwining of postfeminist sexual empowerment and consumption. The discourse surrounding Girls sought to construct a similar series of distinctions between Girls, its HBO predecessor and its network comedy cousins, here operating around authorship and 'authenticity'.

Taylor Nygaard (2013) suggests that Lena Dunham was a strategic choice for HBO as it attempted to regain the female audiences it had lost after Sex and the City drew to a close. Girls joined the political satire Veep (2012-) and the pitch-black corporate comedy of Enlightened (2013-14) to offer distinct variations on the unruly woman sitcom (Karlyn 1995), challenging HBO's brand identity of masculine, anti-hero-led, prestige drama. Whilst Veep and Enlightened could be aligned with HBO's brand identity via the star cachet of their female leads, Julia Louis Dreyfus and Laura Dern, and the cult comedy 'auteurs' Armando Ianucci and Mike White, Dunham was more of a challenge. Her debut feature Tiny Furniture (2010) had positioned her as part of the US independent DIY-filmmaking scene, yet she was unknown to the general public; her comedy of twenty-something women's struggle and status as a female showrunner was at odds with the masculine tone of HBO programming. The first cycle of discourse thus sought to position Dunham as auteur and star, signalling Girls' distinctiveness from other comic explorations of femininity and its legitimacy as an HBO product. HBO aggressively courted the twenty-something female demographic that was drifting away from linear television, with a prolific stream of Lena Dunham interviews and profiles accompanying promotional trailers and posters, targeting both the media establishment and online cultural spaces.

Rebecca Mead's 2010 New Yorker profile of Dunham, appearing two years before Girls debuted, had laid the paratextual groundwork for this promotional discourse. Its observations about Dunham and her work served to build the foundations of her nascent auteur identity and recurred throughout the Girls discourse. These were: a focus on her elite upbringing within New York's art world and her precocious maturity; her mining of personal experience for stark comedic narratives; her generation's lack of privacy in life and online; and her freedom with her body onscreen serving as a pre-emptive strike against critique over her size. Dunham is thus positioned as comedy's disruptive Unruly Woman (Karlyn 1995), a key framework for later academic work on Girls (Marghitu and Ng 2013; Jones 2014). These themes become central points of 'evidence' in the discursive framing of both Dunham and Girls' as exceptional and 'authentic'. 
In order to ratify Dunham as an HBO-appropriate auteur and distance Girls from both the delegitimized feminine forms of the preceding network 'girl' sitcoms and the once ground-breaking, but of late culturally derided (Nussbaum 2013) Sex and the City, this discourse sought to gender Dunham's exceptionalism via paratextual positioning. Despite Dunham's intimate comedic engagement with female subjectivity, both Mead and The New York Times' David Carr (2010) align Dunham with New York male comedic auteurs - Larry David and Woody Allen - rather than contemporary female comedic writer-actresses such as Fey, Poehler and Wiig. In doing so they suggest decoding strategies through 'intertextual links to and similarities with other programs' (Gray 2010b, 114-5).

Dunham was also ratified by the mentorship of Hollywood comedy behemoth Judd Apatow, prolific director (40 Year-Old Virgin (2005), Knocked Up (2007)) and producer of a raft of comedies of stymied contemporary masculinity; much like the network 'girl' sitcoms which were assigned male showrunners to make safe potentially disruptive female comedy voices. Although HBO also paired Dunham with an experienced female showrunner in Jenni Konner (who had worked with Apatow on Undeclared (2001-2002)), her role was often minimised in the narrative of Girls' development. Apatow's early television work was engrained with the emotional authenticity and low-key comedy of discomfort that was central to Dunham's emerging comedic brand, aligning Girls with cult teen dramedy Freaks and Geeks (1999-2000) (co-created with Paul Feig), long-enshrined as a cultural touchstone of intricately-observed authenticity.

As Taylor Nygaard notes, this pairing fundamentally undermined Dunham's celebrated status as revolutionary female 'voice' $(2013,373)$, with Apatow's role in the development and production of Girls at HBO central to the creation 'myth' presented in the promotional discourse cycle. His comedic authority also served to legitimate Dunham's littleseen early work, with Tiny Furniture presented as the catalyst of his mentorship. Yet while Apatow legitimated Dunham, his involvement and cinematic 'bromance' brand created tensions with the construction of her female 'authenticity', tensions that emerged in the third cycle of discourse.

Gray argues that in a bid to create 'desire, hope and expectation for [a] show', hype, synergy and promos create textuality and promise value (2010a, 30) and Girls' first promotional trailer, released at the end of 2011, established the programme's premise and distinctive comedic tone. It also frontally positioned reassuring male authorship - 'from executive producer Judd Apatow' appears before Dunham's own creative credit - and closed with Hannah's claim to her parents that she could be "the voice of my generation ... well $a$ voice of $a$ generation". Whilst using a strong comedic beat on the pause, this claim blended with the laudatory press discourse positioning Dunham herself as a generational voice, serving to blur Hannah and Dunham within the paratextual framing of Girls.

\section{Authenticity and Autobiography: The First Cycle}

As Girls moved closer to its premiere official promotional paratexts were joined by press profiles and interviews to produce 'the all-important early frame through which we will examine, react to, and evaluate textual consumption' (Gray 2010a, 26). Emily Nussbaum's cover story for New York magazine served as a key paratextual object within this cycle of industrial discourse. The cover portrait featured Dunham in a camp play of hyper-femininity and claimed Girls as 'revolutionary' whilst Nussbaum argued the programme was 'like nothing else on tv' (2012). Nussbaum's piece solidified the paratextual narratives surrounding the show three weeks before its premiere: Dunham's size and bodily display 
were framed as deliberate and provocative whilst Girls' sexual frankness was 'a revelation'; Dunham was defined as a Millennial over-sharer, mining her life for material and positioned as a generational spokesperson (although her 'voice of a Generation' status is framed as buzz rather than directly assigned). This profile definitively escalated Girls to the status of cultural 'event' through processes of distinction, delineating it from the 'bawdy and flawed' (Nussbaum 2012) network 'girl' sitcoms of the 2011-12 television season via a narrative of legitimated auteur identity and authenticity of experience.

An HBO comedy-turned-cultural event about the sexual and romantic troubles of a quartet of white affluent New York women sounds very familiar. However this first cycle of discourse was at pains to distance the scrappy twenty-somethings of Girls from the professional thirty-somethings of Sex and the City. As Alice Marwick and danah boyd note, authenticity is always manufactured in comparison to an other, 'for something to be deemed authentic, something else must be inauthentic' $(2011,124)$. Thus Nussbaum framed Girls as a 'post-Sex and the City' show (2012), the scrappy indie sister who is 'raw and bruised not aspirational' (2012). The consumerist lifestyles of Sex and the City's 'bourgeois bohemians' had constructed 'expressions of the different moods and personalities of embodied, empathetic characters in an authentic setting' of boom-time New York (Arthurs 2003, 48). However, its postfeminist glamour and gay male showrunner are positioned by the press as the bad object in this first cycle of discourse (suppressing the extensive involvement of female writers across the programme's life), positioned against Dunham's 'authentic' female voice. Offering frank talk about bodies and sex that was 'even more awkward and bittersweet' than its predecessor (Itzkoff 2012), Girls was presented as the 'recession-era adjustment' (Bruni 2012) to the wealth of Sex and the City's professional thirty-something women, offering 'a world where awkwardness always trumps glamour' (Press 2012).

This first cycle of promotional discourse paid significant attention to Dunham's rarity in the US televisual landscape as a twenty-something female actor/writer/showrunner with extensive creative control (Nussbaum 2012; Ryan 2012a). To legitimate this young, relative unknown as the lone woman within HBO's stable of white male showrunners her 'auteur' status and star identity needed to be built from scratch. Dunham's gendered authorship oscillates within this discourse; as I have noted she is aligned with male comic auteurs to legitimate her place in HBO's schedules, yet her female authorship is foregrounded to construct her 'authentic' vision of female experiences. Central markers of this vision are highlighted as Girls' comedy of discomfort and female intimacy; Dunham's preference for depicting sex as awkward, uncertain and stumbling and her freedom with her body. None of her more televisually 'normative' female cast-mates shared this bodily display and thus the camera's gaze and the cultural conversation were centralised on Dunham's 'fleshy' form (Bruni 2012; Press 2012). This term and the continual focus on Dunham's physicality suggested an unease at its prominence, yet the discourse simultaneously positions her nakedness as a confrontational act (Nussbaum 2012; Poniewozik 2012) due to its form and presentation disrupting the cultural mould of the naked woman as object of pleasure. This echoes Helen Warner's analysis of the critical discomfort at Bridesmaids' use of gross-out comedy spectacle and fatness, the comedy of the disruptive 'unruly women' unsettling patriarchal standards of appropriate female humour (Warner 2013). Dunham observes to Nussbaum that 'I know it's going to gross some people out. There's people who don't want to see bodies like mine or bodies like their own bodies' (2012). Thus both she and the discourse embed her 'authenticity' in her 'flawed' femininity, within a televisual landscape where the 'adorkability' of New Girl's petite, doe-eyed Zooey Deschanel - whose quirky nerdiness offers an unthreatening model of unruliness - was the network model $d u$ jour. 
Dunham is positioned throughout as an 'oversharer', with her strong online presence feeding into a complex celebrity persona, which blended an 'authenticity' articulated through Girls' affect and physicality with the glamour of Dunham's New York lifestyle. Elizabeth Ellcessor takes up existing models of stardom as articulated through both performance and extratextual discourse augmented by social media, suggesting success here 'relies on precisely the intimacy and authenticity considered so central to television celebrity' (2012, 51). Dunham built an intimate connection with her online followers and chronicled the production of Girls via her Twitter and Instagram accounts, whose confessional format assisted in the cultural blurring of herself and Hannah.

This autobiographical blurring was accentuated by the tendency to paint Girls as drawn directly from Dunham's own twenty-something struggles, presented as evidence of the programme's 'authenticity'. Girls co-showrunner Jenni Konner explained how Dunham sourced stories from her own life (Nussbaum, 2012), later claiming this produced frequent wrangles with HBO lawyers (Martin 2013). Dunham herself oscillated between asserting distance from and closeness to her characters, suggesting this was her least autobiographical project (Nussbaum 2012) only to later claim that 'each character was a piece of me or based on someone close to me' (NPR 2012). Such centralising of Dunham's 'voice' - tying Girls so tightly to her authorship - ultimately made her a target of critique in later cycles of discourse. Marwick and boyd note that authenticity is not universal, that 'the authentic is a localized, temporally situated social construct' (2011:124), and so Girls' 'authenticity' came to be contested.

Jonathan Gray suggests that hype can play a role in 'creating the show as a meaningful entity for "viewers" even before they become viewers, or even if they never become viewers' (2010a, 18). The first cycle's paratextual positioning of Dunham as an authentic, disruptive, generational voice shaped its potential audience's reading strategies, creating expectations of naturalism, realism and universality within its depiction of Millennial women's experience. These narrratives were then echoed by US television critics in the second cycle of paratextual discourse.

\section{Critical Consensus - The Second Cycle}

Television critics offered widespread consensus - Girls was second only to Showtime's Homeland (2011-) as the critical favourite of the 2011-12 season (VanDerWerff 2012). Gray positions press reviews as playing 'a unique mediating role' in audiences' reception of television, as they promise neutrality and objectivity and are supported by 'authoritative, insider information' (Gray 2010b, 115). The interpretive community of television critics coalesced with themes pushed by the industrial discourse to solidify the paratextual framing of Girls. Dunham offered a distinct, fully-formed 'voice' and 'vision' (Poniewozik 2012; Sepinwall 2012b; Goodman 2012) and Girls was 'raw, audacious, nuanced and richly, often excruciatingly funny' (Poniewozik 2012); 'smart, bracing, funny, accurately absurd, confessional yet self-aware' (Paskin 2012); 'witty and wise and warm and not exactly like anything you've heard before' (Sepinwall 2012b); 'a fresh and wonderfully realized show that feels like nothing else on TV' (Ryan 2012a); a 'rooted-in-realism affair' that 'mines the honesty of its characters' (Goodman 2012). Here we see a consistent reading strategy framing Girls as an 'authentic' and original comedy of female experience, legitimating Dunham's comic voice as distinct from the network 'girl' sitcoms and appropriate for the culturally elite HBO. 
Primarily employed by news and culture websites, these influential US television 'taste leaders' nevertheless mirror the overwhelmingly white, middle-class male newsrooms of traditional print media (Hilton 2014) and offer analysis focused on story, genre and industrial concerns. The few critics who consistently step back to consider political or cultural angles are primarily women (Alyssa Rosenberg at the Washington Post, Willa Paskin at Slate) and men of colour (Eric Deggars at National Public Radio). Dunham's authorship and Girls' focus on the complexities of female friendship was celebrated by prominent female TV critics such as Mo Ryan, Paskin and Nussbaum ${ }^{\text {iv }}$ who had consistently observed US television's limited opportunities for women. Although both Nussbaum (2012) and Paskin (2012) spoke of their personal connections with Dunham's characters they also recognized the show's 'confounding' whiteness and its characters entitlement. These briefly addressed concerns would later blossom in the third cycle, where different 'interpretive strategies' (2010b, 116) pushed back against the established critical gatekeepers.

In a bid to tempt potential subscribers HBO made the Girls pilot available free for US viewers on YouTube after its April $15^{\text {th }}$ premiere. The pilot became a piece of spreadable media, serving to stoke the cultural conversation that was building to fever pitch, around sex scenes and pornography, normative femininity and bodily display, authorship and nepotism, privilege and Millennial ennui. The early hype and critical discourse positioned Girls as an authentic, original vision of young womanhood, yet voices emerged problematising this idea, noting that for a show that was 'like nothing else on TV' (Nussbaum 2012), its world seemed starkly familiar. The much-vaunted display of disruptive, unruly femininity was wrapped up in a safe white, upper-middle class, heterosexual milieu. Commentaries on Girls became a cottage industry, driving page-views across the Internet, with this critique doing valuable work in bringing concerns around television representation from the niche spaces of women's websites into mainstream press discourse.

\section{Setting the Online Scene - The Third Cycle}

While the TV critics' discourse worked largely in a top-down model of communication, seeking to advise their readers, this third cycle of commentary emerged from an online landscape of participatory culture, one built on connections and conversations (Ellcessor 2012, 49). I here focus primarily on commentary from prominent women's websites (Jezebel, The Hairpin, Racialicious) which shared an imagined audience with Girls, particularly those websites built on the 'playful activism' Jessalynn Keller identifies in contemporary online feminism $(2011,12)$. These websites interweave sharp-tongued cultural and political commentary with quick wit, mockery and satire. Their intimate, confessional, comic voice at times echoes Dunham's sensibility and subject matter and they share Girls' target audience of educated, liberal, young women. Thus these websites took a particular interest in the programme that previous cycles of discourse had asserted spoke for 'them'.

Keller highlights how contemporary online feminist activism crosses between subcultural spaces and the mainstream $(2011,4)$, constructing a 'feminist community that not only consists of a range of networks and connections, but also a diversity of voices, goals, and interests that characterize the third wave' $(2011,9)$. The 'messiness' that Keller suggests complicates 'the notion of a unified social movement with a clear agenda and boundaries' $(2011,5)$ is in fact a central value and pleasure of contemporary online discourses around race, gender and sexuality in popular culture. This 'messiness' constructs a productive conversation that pulls out cultural tensions through a diversity of viewpoints. These sites had developed strong female commenting communities and were building writing pools that sought to reflect the ethnic diversity of the US Millennial generation (Rosentiel 2009). This 
was in marked contrast to the whiteness of the television executives, journalists and critics who guided the previous cycles of discourse, and Girls' own writers room (in line with much of US television (Ryan 2012b; James 2012)). Whilst undoubtedly centred on a liberal middleclass demographic, the conversations on women's websites sought to negotiate an intersectional (Crenshaw, 1991), third-wave feminist worldview; pushing back against popular culture's populist embrace of the white middle-class world of consumer-led postfeminism.

These environments offered reading strategies constructed in direct response to the framings solidified by the first two cycles. Girls fed into these sites' discussions regarding televisual representations and female authorship, the political potential of feminist comedy, the experiences and voices of people of colour, body politics and sexuality. The programme's cultural visibility provided a space to talk through the complexities of contemporary femininities, yet the intimate emotional connections encouraged by Girls and Dunham's star identity meant critiques provoked tensions within and across these online interpretive communities. This commentary continued throughout the show's first and second seasons, but I focus here on a selection of early responses focused around race. In confronting Girls' marginalisation of people of colour these commentaries unsettled its status as a progressive vanguard of feminist comedy, disrupting the discourse of 'authenticity' by aligning the programme with existing televisual norms of whiteness.

\section{White Girls}

Jenna Wortham at The Hairpin (2012), Kendra James at Racialicious (2012) and Dodai Stewart at Jezebel (2012) offered key commentaries in the days following the premiere, focused on the central question "why are the only lives that can be mined for "universal experiences" the lives of white women?' (James 2012). The discourse of universality around Girls highlights the inability of many earlier journalists and critics to recognise its whiteness, illustrating Richard Dyer's observation that 'the position of speaking as a white person is one that white people now almost never acknowledge and this is part of the condition and power of whiteness: white people claim and achieve authority for what they say by not admitting, indeed not realising, that for much of the time they speak only for whiteness' (1997, xiv). These women shared the lifestyles and privileged backgrounds of the protagonists of Girls 'They are us but they are not us. They are me but they are not me' (Wortham, 2012). Yet they questioned how Dunham could conceive of 'such [a] radically different [image] of New York City?' (James, 2012), one largely absent people of colour, who when present were coded as working class, subjected to a further 'othering'. Girls' 'universality' and 'authenticity' here fell short by requiring women of colour to read themselves onto white women, in line with the existing comedies of New York womanhood that the previous cycles of discourse had sought to distinguish Girls against.

All three women pointed to the discursive framing of the programme as a modern, revolutionary comedy of young womanhood, 'like nothing else on television', yet they highlighted its continuity, creating the 'message that time after time, that no one cares about us, and Girls just joins the throngs of the indifferent' (Stewart, 2012). Thus Girls served as a valuable site for writers of colour to talk through the complexity of cultural representation and marginalisation, making visible Dyer's assertion that 'White people have power and believe that they think, feel and act like and for all people; white people, unable to see their particularity, cannot take account of other people's' (1997, 9). Stewart and Wortham framed 
their dismay as hitting so hard due to Girls vaunted emotional realism, its intimacy of female friendship and twenty-something struggle:

The problem with Girls is that while the show reaches - and succeeds, in many ways - to show female characters that are not caricatures, it feels alienating, a party of four engineered to appeal to a very specific subset of the television viewing audience, when the show has the potential to be so much bigger than that. (Wortham, 2012)

Controversy around racial representations in television comedy had already emerged that season around another 'girl' sitcom, CBS's 2 Broke Girls, with showrunner Darren Star involved in a heated confrontation with TV critics at a press event over the programme's use of regressive racial stereotypes (Sepinwall 2012a). Yet, whilst 2 Broke Girls was a critically maligned text, here was a critically cherished text having its own diversity issues highlighted, prompting defensive responses. TV critic Mo Ryan argued that 'Girls adds greatly to television's diversity by reflecting a worldview not often seen on the small screen' (2012b), yet in doing so she suggested a hierarchy of televisual 'otherness' with space only to transgress one 'norm' at a time. Ryan and fellow critic Alyssa Rosenberg (2012b) made valuable points about the institutionalised nature of whiteness within television as a whole, with Ryan questioning 'Why are we holding Lena Dunham's feet to the fire, instead of the heads of networks and studios?' (Ryan 2012b). These tensions were the direct result of TV critics' own contributions to earlier cycles of discourse that tied Girls so tightly to Dunham's authorship and 'authentic' voice. In celebrating the programme as a direct product of Dunham's creative control rather than HBO's industrial guidance, choices about race inevitably become attributed to the televisual 'auteur' rather than to wide-scale institutional defaults to whiteness. Thus the discourses of legitimation that sought to distinguish Girls from other comedies of dysfunctional New Yorkers ultimately served to solidify it as a target for critique.

This early swirl of critique fomented a quickly-deleted tweet in response to Wortham's piece from Lesley Arfin - a member of the Girls writers room whose labour had been largely obscured in the narrative of Dunham and Apatow's authorship - "What really bothered me most about Precious was that there was no representation of ME" (Stewart 2012). This flippant reference to the Oscar-nominated film about a young woman of colour's struggle with urban poverty kicked off its own eddy of discussion around 'hipster racism' and frustration at the Girls creative team's disinterest in the voices of women of colour (Stewart 2012; Read 2012; West 2012). Arfin's tweet stepped into the vacuum left by Dunham, who in a decisive shift from her previous use of the intimacy and immediacy of social media elected not to address the issue on these platforms. Marwick and boyd note the difficulty of managing a unified presentation of self on Twitter, noting that 'social media collapse diverse social contexts into one, making it difficult for people to engage in the complex negotiations needed to vary identity presentation, manage impressions, and save face' $(2011,123)$. This may be why Dunham chose to address debate on National Public Radio's respected interview programme Fresh Air. Here she tied Girls closely to her own experience and authorship, reasserting her discursive position as intimate comic auteur. Continuing the erasure of the writers room labour, she claimed she wrote the first season largely independently, framing her creation of four white protagonists as an 'accident' due to writing from a 'gut-level' (NPR 2012).

Dyer's suggestion that 'white people create the dominant images of world and don't quite see that they thus construct the world in their own image' $(1997,9)$ is borne out by Dunham's explanation that she wrote 'something that was super-specific to my experience, 
and I always want to avoid rendering an experience I can't speak to accurately' (NPR 2012). Dunham' default to whiteness is thus folded into the central discourse of her own and Girls' authenticity, inferring that any attempt to recognise women of colour would impair the accuracy of her vision. As Cord Jefferson noted at cultural website Gawker 'When we look at Lena Dunham and Jerry Seinfeld, we see people with whom we have a lot in common. When they look at us, they see strangers' (Jefferson 2012). This third cycle of paratextual commentary thus catalysed discussions of television's default to whiteness, even within texts positioned as progressive.

\section{Conclusions}

I have only addressed the tip of the iceberg regarding online discourse around Girls and race, not to mention the conversations around body image, young women's sexuality, privilege and gender in prestige television that continued throughout its first two seasons. However, some of these gaps are covered by Marghitu and $\mathrm{Ng}$ (2013) and Jones (2014), particularly the discourses surrounding postfeminism and women's bodies. A more thorough charting of the cycling of these conversations through other websites, personal blogs, reader comments and social media could serve as an illuminating case study of spreadability in online discussions of television, and the struggle for intersectionality in contemporary online feminism (Adewunmi 2012; Loza 2014). Arguably this third cycle mutated into something more problematic, with the early thoughtful critiques becoming collateral for misogynistic attacks on Dunham taking place in the public comments on internet articles, ${ }^{\mathrm{v}}$ a space where attacks on Girls and attempts to devalue Dunham's worth as a female comedy creator were heavily tied into her appearance and bodily representations (Rosenberg 2012c). Such attacks on female creatives, noted TV critic Alyssa Rosenberg, illustrate some men's resistance to the rebalancing of cultural power dynamics, particularly the patriarchal 'power to judge women who they've been taught are in need of their evaluation and correction that can only come from outside them' (2012c).

The UK saw its own cycle of Girls critique when the programme debuted on Sky Atlantic in Autumn 2012, which often ignored the perceptive commentary that had already been worked through in the US cycles of discourse. This was particularly evident in discussions of intersectionality, including a storm of controversy about a flippant tweet from journalist Caitlin Moran dismissing concerns over Girls' racial representations (Adewunmi 2012). In both the US and UK the conversation around Girls served to bring greater visibility to discussions of the politics of representation in popular culture that was always already taking place on women's websites. It formed one facet of growing engagement in feminism amongst young women, fed by Tumblr and social media activism, together with female stars such as Dunham, pop star Beyonce and actresses Emma Watson and Jennifer Lawrence. Feminism arguably became a brand and a commodity, yet this resurgence of activism spoke with a reinvigorated political voice fed by social media and women's websites, with the intersectional concerns long ignored by postfeminism at the forefront of these debates (Loza 2014; Cochrane 2013).

Feminist comic voices grew in stature, from award-winning British stand-up Bridget Christie to the critical and ratings success of US basic cable channel Comedy Central's development of female-authored and starring comedies. Sketch show Inside Amy Schumer (2013-) and sitcom Broad City (2014-) - the latter developed from a web series and executively produced by Amy Poehler - debuted with significantly less hype than Girls as 
Comedy Central did not strive for HBO legitimation. Both programmes were warmly welcomed by women's websites, whilst Broad City's scrappy, racially diverse vision of New York and its pair of unruly twenty-something women lightened the burden on Girls, which no longer had to claim universality. Whilst these were still largely white comic voices, now questions around racial representations were a prominent part of the cultural conversation; small steps were being made. 2014 saw Saturday Night Live adding two women of colour to its cast and in $2015 \mathrm{HBO}$ greenlit a long-gestating pilot from Issa Rae, creator of the web series The Mis-adventures of Awkward Black Girl (2011-2013).

In charting the three cycles of debate Girls generated as it debuted on HBO, I have identified key discourses surrounding Girls and Lena Dunham. Here 'authenticity', originality and universality sought to construct Dunham's identity as a female auteur and legitimize both her and her comedy of twenty-something femininity within the masculine prestige of the HBO channel brand. While such 'authenticity' was initially supported by critics this discourse confronted resistance from online cultural commentary, making plain the default to whiteness in television production and criticism. This example demonstrates how online networked spaces and niche communities can intervene and talk back to dominant cultural ideologies. By plotting Girls' position in cultural conversations around channel identity, comic voice, race and gender representation, prestige television and gendered authorship I have illustrated how the programme served as touchstone to productively work through industrial and cultural tensions, via 'Girls talk'.

2 Broke Girls. 2011-. CBS, Michael Patrick Kind Productions / Warner Bros. Television 30 Rock. 2006-2013. NBC, NBC Studios / Broadway Video / Little Stranger 40 Year Old Virgin. 2005. Directed by Judd Apatow. US: Universal Pictures / Apatow Productions

Adewunmi, Bim. 2012. "What the Girls Spat on Twitter Tells Us about Feminism." Guardian, 8 October. Accessed 10 October 2012. http://www.theguardian.com/commentisfree/2012/oct/08/girls-twitter-feminismcaitlin-moran.

Amanda Ann Klein. 2012. "Reconsidering GIRLS.” Judgmental Observer, 19 May. Accessed 13 July 2012. http://judgmentalobserver.com/2012/05/19/reconsideringgirls/.

Arthurs, Jane. 2003. "Sex and the City and Consumer Culture: Remediating Postfeminist Drama." In Feminist Television Criticism: A Reader, edited by Charlotte Brunsdon and Lynn Spigel, 2nd ed., 41-56. Maidenhead: Open University Press.

Broad City. 2014-. Comedy Central, 3 Arts Entertainment / Jax media / Paper Kite Productions.

Bridesmaids. 2011. Directed by Paul Feig. US: Universal Pictures / Relativity Media / Apatow Productions.

Brown, Mary Ellen. 1994. Soap Opera and Women's Talk: The Pleasure of Resistance. Thousand Oaks: SAGE Publications, Inc.

Bruni, Frank. 2012. "The Bleaker Sex." New York Times, 31 March. Accessed 7 July 2014. http://www.nytimes.com/2012/04/01/opinion/sunday/bruni-the-bleaker-sex.html.

Carr, David. 2010. "Young Filmmaker's Search for Her Worth Is Rewarded." New York Times, 20 March. Accessed 27 August 2014. http://www.nytimes.com/2010/03/20/movies/20tiny.html. 
Carter, Bill. 2011. “This Year's Hot TV Trend Is Anatomically Correct.” New York Times, 21 September. Accessed 27 August 2014.

http://www.nytimes.com/2011/09/22/arts/television/this-years-hot-tv-trend-is-aword.html.

Cochrane, Kira. 2013. "The Fourth Wave of Feminism: Meet the Rebel Women." Guardian, 10 December. Accessed 27 August 2014.

http://www.theguardian.com/world/2013/dec/10/fourth-wave-feminism-rebel-women.

Crenshaw, Kimberle. 1991. "Mapping the Margins: Intersectionality, Identity Politics, and Violence against Women of Color." Stanford Law Review 43 (6): 1241-99.

Don't Trust the B--- in Apartment 23. 2012-2013. ABC, $20^{\text {th }}$ Century Fox Television / ABC Studios / Hemingson Entertainment

Dyer, Richard. 1997. White. London: Routledge.

Ellcessor, Elizabeth. 2012. "Tweeting@feliciaday: Online Social Media, Convergence, and Subcultural Stardom." Cinema Journal 51 (2): 46-66.

Enlightened. 2011-2013. HBO, HBO Entertainment / Rip Cord Productions.

Freaks and Geeks. 1999-2000. Dreamworks Television / Apatow Productions.

Girls. 2012-. HBO, Apatow Productions.

Goodman, Tim. 2012. "Review: 'Girls' Is Brilliant Gem For HBO." The Hollywood Reporter, 11 March. Accessed 27 August 2014. http://www.hollywoodreporter.com/bastard-machine/review-girls-lena-dunhambrilliant-HBO-298379.

Gray, Jonathan. 2010a. Show Sold Separately: Promos, Spoilers, and Other Media Paratexts. New York: New York University Press.

. 2010b. "The Reviews Are in: TV Critics and the (pre)creation of Meaning." In

Flow TV: Television in the Age of Media Convergence, edited by Michael Kackman, Marnie Binfield, Matthew Thomas Payne, Allison Perlman, and Bryan Sebok, 11427. Abingdon: Routledge.

Hess, Amanda. 2014. “The Next Civil Rights Issue: Why Women Aren't Welcome on the Internet." Pacific Standard. 6 January. Accessed 28 August 2014.

http://www.psmag.com/navigation/health-and-behavior/women-arent-welcomeinternet-72170/.

Hilton, Shani O. 2014. "Building A Diverse Newsroom Is Work." Medium, 14 March. Accessed 15 March 2014. https://medium.com/@shani_o/building-a-diversenewsroom-is-work-e4843d6d014b.

Inside Amy Shumer. 2013-. Comedy Central, Jax Media.

Itzkoff, Dave. 2012. "Cable's New Pack of Girls, Trying on the Woman Thing." The New York Times, 2 March. Accessed 27 August 2014. http://www.nytimes.com/2012/03/04/arts/television/lena-dunham-on-girls-her-newhbo-comedy.html.

James, Kendra. 2012. "Dear Lena Dunham: I Exist.” Racialicious. 19 April. Accessed 20 April 2012. http://www.racialicious.com/2012/04/19/dear-lena-dunham-i-exist/.

Jefferson, Cord. 2012. "Hipster Racism Runoff And The Search for The Black Costanza." Gawker. 27 April. Accessed 29 April 2012. http://gawker.com/5905885/hipsterracism-runoff-and-the-search-for-the-black-costanza.

Jenkins, Henry, Sam Ford, and Joshua Green. 2013. Spreadable Media: Creating Value and Meaning in a Networked Culture. New York; London: NYU Press.

Jones, Jennifer Lynn. 2014. "Fat Funny People: Corpulence and the Apatow Brand." Paper presented at the annual Society for Cinema and Media Studies conferece, Seattle, 19-23 March. 
Karlyn, Kathleen Rowe. 1995. The Unruly Woman: Gender and Genres of Laughter. Austin, Tex: University of Texas Press.

Keller, Jessalynn Marie. 2011. "Virtual Feminisms." Information, Communication \& Society 15 (3): 429-47.

Knocked Up. 2007. Directed by Judd Apatow. Universal Pictures / Apatow Productions.

Loza, Susana. 2014. "Hashtag Feminism, \#SolidarityIsForWhiteWomen, and the Other \#FemFuture." Ada: A Journal of Gender, New Media, and Technology 5 (July). http://adanewmedia.org/2014/07/issue5-loza/.

Marghitu, Stefania, and Conrad Ng. 2013. "Body Talk: Reconsidering the Post-Feminist Discourse and Critical Reception of Lena Dunham's Girls." Gender Forum, 45. http://www.genderforum.org/issues/special-issue-early-career-researchers-i/bodytalk-reconsidering-the-post-feminist-discourse-and-critical-reception-of-lenadunhams-girls/.

Martin, Denise. 2013. “The Grown-up Behind Girls: Jenni Konner.” Vulture. 17 January. Accessed 23 July 2014. http://www.vulture.com/2013/01/grown-up-behind-girlsjenni-konner.html.

Marwick, Alice E., and danah boyd. 2011. "I Tweet Honestly, I Tweet Passionately: Twitter Users, Context Collapse, and the Imagined Audience.” New Media \& Society 13 (1): 114-33.

Mead, Rebecca. 2010. “Downtown's Daughter.” The New Yorker. 8 November. Accessed 30 July 2014. http://www.newyorker.com/magazine/2010/11/15/downtowns-daughter.

Mizejewski, Linda. 2014. Pretty/Funny: Women Comedians and Body Politics. Austin: University of Texas Press.

Newman, Michael Z., and Elana Levine. 2011. Legitimating Television: Media Convergence and Cultural Status. Abbingdon: Routledge.

NPR. 2012. "Lena Dunham Addresses Criticism Aimed At 'Girls."” NPR.org. 7 May. Accessed 20 April 2013. http://www.npr.org/2012/05/07/152183865/lena-dunhamaddresses-criticism-aimed-at-girls.

Nussbaum, Emily. 2011. "Crass Warfare.” The New Yorker. 21 November. Accessed 27 August 2014. http://www.newyorker.com/magazine/2011/11/28/crass-warfare. . 2012. "It's Different for 'Girls."” New York. 25 March. Accessed 30 April 2013. http://nymag.com/arts/tv/features/girls-lena-dunham-2012-4/. - 2013. "Difficult Women." The New Yorker, 29 July. Accessed 27 August 2014. http://www.newyorker.com/arts/critics/television/2013/07/29/130729crte_television_ nussbaum? currentPage $=$ all.

Nygaard, Taylor. 2013. “Girls Just Want to Be 'Quality': HBO, Lena Dunham, and Girls' Conflicting Brand Identity." Feminist Media Studies 13 (2): 370-74.

Park and Recreation. 2009-2015. NBC, Universal Media Studios / Deedle-Dee Productions / 3 Arts Entertainment

Paskin, Willa. 2012. “'Girls' Lives up to the Hype.” Salon. 12 April. Accessed 30 April 2013. http://www.salon.com/2012/04/12/girls_lives_up_to_the_hype/.

Petersen, Anne Helen. 2014. "Acknowledging the Dystopia: Girls and Post-Postfeminism." Paper presented at the annual Console-ing Passions conference, Columbia, 10-12 April 2014.

Poniewozik, James. 2012. "Dead Tree Alert: Brave New Girls.” Time, 5 April. Accessed 27 August 2014. http://entertainment.time.com/2012/04/05/dead-tree-alert-brave-newgirls/.

Precious. 2009. Directed by Lee Daniels. US, Lionsgate / Lee Daniels Entertainment / Smokewood Entertainment Group. 
Press, Joy. 2011. “Edgy Women like 'Whitney’ Lead the Fall TV Lineup.” Los Angeles Times, 15 September. Accessed 27 August 2014.

http://articles.latimes.com/2011/sep/15/entertainment/la-et-edgy-women-20110915. . 2012. "Lena Dunham Speaks Uncomfortable Truths about 'Girls.”' Los Angeles Times, 8 April. Accessed 27 August 2014.

http://articles.latimes.com/2012/apr/08/entertainment/la-ca-lena-dunham-20120408.

Read, Max. 2012. "A Girls Writer's Ironic Racism And Other 'White People Problems."” Gawker, April 20. Accessed 22 April 2012. http://gawker.com/5903468/a-girlswriters-ironic-racism-and-other-white-people-problems.

Rosenberg, Alyssa. 2012a. "What This Year's Female-Driven Comedies Can — and Can'tDo For Women In TV and at Home." Think Progress, 22 March 22. Accessed 27 August 2014. http://thinkprogress.org/alyssa/2012/03/22/449194/what-this-yearsfemale-driven-comedies-canand-cantdo-for-women-in-tv-and-at-home/. . 2012b. "The Other 'Girls' and Diversity Goals for Pop Culture." Think Progress, 18 April. Accessed 27 August 2014.

http://thinkprogress.org/alyssa/2012/04/18/466139/the-other-girls-and-diversitygoals-for-pop-culture/.

.2012c. "Lena Dunham's Looks, the Misogyny of the 'Girls' Backlash, and Staying In Your Assigned Story.” Think Progress. 29 May. Accessed 27 August 2014. http://thinkprogress.org/alyssa/2012/05/29/491372/lena-dunham-girls/.

Rosentiel, Tom. 2009. "The Millennials." Pew Research Center. 10 December. Accessed 27 August 2014. http://www.pewresearch.org/2009/12/10/the-millennials/.

Ryan, Maureen. 2012a. “'Girls' Review: Lena Dunham's Frank And Fearless Debut.” Huffington Post. 12 April. Accessed 27 August 2014.

http://www.huffingtonpost.com/maureen-ryan/girls-review-lenadunham_b_1419061.html. . 2012b. "HBO's 'Girls' Isn't Racist, Television Is Racist (And Sexist)." Huffington Post. 25 April. Accessed 27 August 2014. http://www.huffingtonpost.com/maureenryan/girls-hbo-racist_b_1451931.html.

Saturday Night Live. 1975-. NBC, NBC Universal Television / Broadway Video.

Sepinwall, Alan. 2012a. "Press Tour: '2 Broke Girls' Panel Turns Ugly with Racism, Raunchiness Charges." HitFix. 11 January. Accessed 27 August 2014. http://www.hitfix.com/blogs/whats-alan-watching/posts/press-tour-2-broke-girlspanel-turns-ugly-with-racism-raunchiness-charges.

. 2012b. "Review: HBO's 'Girls' Brilliantly Channels Lena Dunham's Comic Voice." HitFix. 12 April. Accessed 27 August 2014. http://www.hitfix.com/blogs/whats-alanwatching/posts/review-hbos-girls-brilliantly-channels-lena-dunhams-comic-voice.

Sex and the City. 1998-2004. HBO, Darren Star Productions / HBO.

Silverstein, Melissa. 2012. "Lena Dunham's Show Girls - Yes, It Is That Good.” Women and Hollywood, 12 April. Accessed 27 August 2014.

http://blogs.indiewire.com/womenandhollywood/lena-dunhams-show-girls-yes-it-isthat-good.

Stewart, Dodai. 2012. "Why We Need to Keep Talking About the White Girls on Girls."

Jezebel. 19 April. Accessed 20 April 2012. http://jezebel.com/5903382/why-we-needto-keep-talking-about-the-white-girls-on-girls.

The Misadventures of Awkward Black Girl. 2011-2013. YouTube, Issa Rae Productions.

Tiny Furniture. 2010. Directed by Lena Dunham. US, Tiny Ponies.

Undeclared. 2001-2003. FOX, Dreamworks Television / Apatow Productions.

VanDerWerff, Todd. 2012. "How Girls Challenges the Masculine Expectations of 'good TV."” A.V. Club. 14 June. Accessed 27 August 2014. 
http://www.avclub.com/article/how-igirlsi-challenges-the-masculine-expectations-81266.

Veep. 2012-. HBO, Dundee Productions

Warner, Helen. 2013. “A New Feminist Revolution in Hollywood Comedy'?: Postfeminist Discourses and the Critical Reception of Bridesmaids'." In Postfeminism and

Contemporary Hollywood Cinema, edited by Joel Gwynne and Nadine Muller, 22237. Basingstoke: Palgrave Macmillan.

West, Lindy. 2012. "A Complete Guide to 'Hipster Racism." Jezebel, 26 April. Accessed 27 August 2014. http://jezebel.com/5905291/a-complete-guide-to-hipster-racism.

Wheatley, Helen. 2013. "Loving Girls." CST Online, 29 March. Accessed 30 March 2013. http://cstonline.tv/loving-girls.

Wortham, Jenna. 2012. “Where (My) Girls At?” The Hairpin. 16 April. Accessed 16 April 2012. http://thehairpin.com/2012/04/where-my-girls-at/.

\footnotetext{
${ }^{\mathrm{i}}$ As this authenticity is itself a discursive construct I position it within quote marks throughout.

ii Although there is a large and valuable academic discussion of 'quality' television, I prefer 'prestige' as a term currently used within critical circles. This term makes plain the legitimation process and absents the automatic assignment of value that necessitates any use of quality as a discursive term to be accompanied with quote marks.

${ }^{\text {iii }}$ While all the sites here engage with popular culture I distinguish between those with a general audience and focused on the arts and media as 'culture websites' and I use 'women's websites' to refer to those with a niche female target. I include in this category both general interest blogs targeted at women, with a strong feminist point of view - Jezebel, The Hairpin - and those with a stronger advocacy focus - Feministing, Racialicious, The F Word.

iv Nussbaum wrote long-form journalism such as the New York magazine cover story as well as covering television for magazine, and has since moved to The New Yorker.

${ }^{\mathrm{v}}$ Whilst she does not discuss Girls this landscape is articulated effectively by Hess (2014).
} 